\title{
Cyber Child Grooming sebagai Bentuk Kekerasan Berbasis Gender Online di Era Pandemi
}

\author{
Imara Pramesti Normalita Andaru \\ Fakultas Ilmu Sosial Ilmu, Politik Universitas Sebelas Maret \\ "Penulis Koresponden: Imaraandaru@gmail.com
}

\section{ABSTRAK}

Kita ketahui bahwa semakin maju dan berkembangnya teknologi tentu akan memiki dampak positif dan negatifnya juga. Dari segi positif, internet atau media sosial dapat memberikan berbagai informasi dan pengetahuan, demikian juga dapat berkomunikasi dengan orang lain tanpa bertatap muka. Namun dari sisi negatif, kehadiran internet atau media sosial ini dapat menimbulkan berbagai tindak modus kejahatan dengan memanfaatkan kemajuan teknologi. Salah satu tindak kejahatan yang meningkat di era pandemi adalah Kekerasan Berbasis Gender Online (KBGO) dalam bentuk cyber grooming. Adanya pandemi Covid-19 menyebabkan cyber grooming pada anak semakin meningkat, dikarenakan selama pandemi masyarakat lebih banyak melakukan kegiatan di rumah, terutama anak-anak banyak menggunakan gadget dan disalahgunakan. Penelitian ini akan menggunakan metode kualitatif dengan teknik pengumpulan data dan jenis penelitian deskriptif analitis. Penelitian ini bertujuan untuk mengetahui bagaimana $c y b e r$ grooming pada anak meningkat di era pandemi Covid-19, apa yang menjadi penyebab adanya cyber child grooming dan bagaimana dampaknya.

Kata Kunci: teknologi; media sosial; Cyber Grooming; Child Grooming

\section{ABSTRACT}

We know that the more advanced and developed technology, of course, will have positive and negative impacts as well. From the positive side, the internet or social media can provide a variety of information and knowledge as well as can communicate with other people without meeting face to face. However, from the negative side, the presence of the internet or social media can lead to various modes of crime by taking advantage of technological advances. One of the increasing crimes in the pandemic era is Online Gender Based Violence (OGBV) specifically here is cyber grooming. The existence of the Covid-19 pandemic has caused cyber grooming in children to increase, because during the pandemic the community did more activities at home, especially children using gadgets a lot and sadly not being used properly. This research will use qualitative methods with data collection techniques and descriptive analytical research type. This study aims to find out how cyber child grooming has increased in the era of the Covid-19 pandemic, and what causes cyber child grooming also how its impact.

Kata Kunci: Technology; Social media; Cyber Grooming; Child Grooming

\section{PENDAHULUAN}

Perkembangan manusia yang terus mengalami kemajuan, tentunya mengalami perubahan dari berbagai aspek, baik berdampak terhadap kemajuan kehidupan tersebut maupun berdampak pada meningkatnya kejahatan dalam kehidupan manusia. Salah satu bentuk kemajuan dalam kehidupan manusia adalah adanya jaringan internet. Seiring berkembangnya dunia teknologi dan adanya internet tersebut, tentu memiliki dampak dari segi positif dan negatif. Salah satu contoh dampak dari segi positif, kehadiran internet dapat menghubungkan antara manusia yang satu dengan manusia yang lain tanpa perlu bertatap muka. Sedangkan dari sisi buruk, kehadiran dunia maya turut menyumbang munculnya berbagai tindak kejahatan yang muncul dengan berbagai modus yang memanfaatkan kemajuan teknologi ini (Salamor, dkk., 2020:490). 
Pandemi Covid-19 yang semakin meluas menyebabkan perubahan besar di kehidupan masyarakat. Adanya kebijakan Sosial Distancing atau pembatasan sosial membuat semua orang lebih memilih untuk menghabiskan waktu di dalam rumah dan bermain gadget. Kebanyakan orang tak terkecuali anak-anak akan menghabiskan waktunya untuk bermain media social seperti, Facebook, Twitter, Instagram, hingga Youtube. Apabila internet atau media social ini tidak ditunjang dengan payung hukum yang kuat, maka banyak orang yang dapat berpotensi sebagai seorang pelaku kejahatan maupun sebagai seorang korban kejahatan, karena hukum sebagai suatu alat yang dapat mengontrol tatanan kehidupan masyarakat dari segala aspek yang menyimpang, entah itu berupa kejahatan maupun pelanggaran.

Merujuk Catatan Tahunan Komnas Perempuan Tahun 2020, mencatat adanya kekerasan terhadap gender jenis baru yaitu kekerasan gender berbasis cyber atau online. Kasus kekerasan ini terus mengalami peningkatan selama enam tahun terakhir, peningkatan sebesar 300\% pada Kekerasan Berbasis Gender Online (KBGO) dibandingkan tahun sebelumnya (2019) (Komnas Perempuan, 2020). Komnas Perempuan menyatakan bahwa kekerasan jenis ini memiliki pola kekerasan yang semakin rumit karena terjadi dalam ranah digital. Mulai dari pembunuhan karakter hingga pelecehan seksual melalui serangan di dunia maya. Dampak KBGO sama seperti kekerasan seksual yang terjadi di dunia nyata, dampaknya dirasakan langsung dan berjangka panjang pada korban. Pelaku sulit dideteksi serta respon dan perlindungan hukum di Indonesia juga belum memadai karena disederhanakan dalam ranah Undang-Undang Informasi dan Transaksi Elektronik. Salah satu jenis kejahatan yang memanfaatkan kemajuan jaringan dunia maya adalah pelecehan seksual. Kejahatan ini tidak hanya menyasar pada orang dewasa, namun juga anak-anak, seperti tindak kejahatan seksual yang dilakukan di media social.

Berdasarkan dari masalah diatas dengan kasus yang terus meningkat, penulisan ini bertujuan untuk mengalisa bagaimana Kasus Kekerasan Berbasis Gender Online (KBGO) salah satunya yakni cyber grooming yang mengarah pada anak. Terdapat beberapa fokus masalah yang akan dibahas dalam penelitian ini mengenai topik yang berkaitan, seperti faktor penyebab cyber child grooming, bentuk-bentuk dan dampaknya.

\section{TINJAUAN PUSTAKA}

Hadirnya internet dan media sosial tidak hanya memiliki dampak positif di kehidupan masyarakat, tapi juga memiliki dampak negatif. Salah satu jenis kejahatan yang sering ditemukan yang mengganggu ketertiban sosial adalah kekerasan. Kekerasan identik dengan perilaku fisik, namun kekerasan pada dasarnya adalah semua bentuk perilaku baik verbal maupun non-verbal yang dilakukan oleh seseorang atau kelompok orang terhadap seseorang atau sekelompok orang lainnya, sehingga menyebabkan efek negatif secara fisik, emosional, dan psikologis terhadap yang menjadi sasarannya (Hardani dan Wilaela, 2010:8). Kekerasan (violence) merujuk pada tingkah laku yang bertentangan dengan undang-undang, baik berupa ancaman saja maupun sudah merupakan suatu tindakan nyata dan memiliki akibat-akibat kerusakan terhadap harta benda atau fisik atau mengakibatkan kematian pada seseorang (Atmasasmita, 2013:66). Menurut Surbakti (2012) Kekerasan terbagi atas dua bagian, yaitu kekerasan fisik dan kekerasan verbal. Tetapi tidak banyak orang tahu kalau kekerasan yang dilakukan secara verbal atau kata-kata ternyata memiliki dampak atau efek yang lebih besar dibandingkan dengan kekerasan fisik (Cooper Julia Marie., 2016).

Berkembang pesatnya teknologi dan media sosial juga menghadirkan jenis-jenis Kekerasan Berbasis Gender yang terjadi di media sosial beragam, yang dapat dikelompokan sebagai berikut: 
a) Pelecehan online (Cyber Harassment), b) Pendekatan untuk memperdaya (Cyber Grooming), c) Peretasan (Hacking), d) Pelanggaran Privasi (Infringement of Privacy), e) Ancaman distribusi foto/video pribadi (malicious distribution), f) Revenge Porn, g) Impersonasi, h) Pencemaran nama baik, i) Rekruitmen online (online recruitment). Indonesia sekarang terdapat bentuk dan motif terbaru yang digunakan untuk menjerat korban yang masih dibawah umur, yaitu dengan menggunakan motif Child grooming. Menurut Ricard J. Gelles (Hurairah, 2012), kekerasan terhadap anak merupakan perbuatan atau tindakan yang disengaja dan dapat menimbulkan kerugian atau bahaya terhadap anak-anak (baik secara fisik maupun emosional). Merujuk pada definisi lembaga internasional Masyarakat untuk Pencegahan Kekejaman terhadap Anak-anak atau National Society for the Prevention of Cruelty to Children (NSPCC), grooming merupakan upaya yang dilakukan seseorang untuk membangun hubungan, kepercayaan, dan hubungan emosional dengan seorang anak atau remaja sehingga mereka dapat memanipulasi, mengeksploitasi, dan melecehkan mereka. Cyber grooming kini telah menjurus ke anak yang disebut sebagai child grooming dan termasuk dalam kejahatan pelecehan seksual. Kekerasan seksual adalah setiap perbuatan yang mencakup pelecehan seksual hingga perbuatan memaksa seseorang untuk melakukan hubungan seksual tanpa persetujuan korban atau di saat korban tidak menghendaki, dan atau melakukan hubungan seksual dengan cara-cara yang tidak wajar atau tidak disukai korban serta menjauhkan (mengisolasi) dari kebutuhan seksualnya (Sulaeman \& Homzah, 2010). Selain itu Pelecehan seksual ialah bentuk kekerasan yang dapat dilakukan oleh siapa saja, dimana saja, dan kapanpun waktunya. Perempuan dan anak adalah orang-orang yang dianggap lemah sehingga sangat berpotensi untuk menjadi korban pelecehan seksual (Purwanti, dkk., 2018: 138). Sedangkan kekerasan seksual terhadap anak menurut End Child Prostitution in Asia Tourism (ECPAT) Internasional, merupakan hubungan atau interaksi antara seorang anak dengan orang dewasa misalnya orang asing, saudara sekandung, atau bahkan orang tua, dimana anak dipergunakan untuk objek pemuas kebutuhan seksual pelaku.

Kasus child grooming terbilang merupakan jenis kejahatan baru di Indonesia. Child grooming di Indonesia atau bisa disebut juga sebagai kejahatan eksploitasi seksual terhadap anak menggunakan media social ini meningkat karena permintaan pasar seks global yang makin besar. Kejahatan ini tentu saja dilarang oleh undang-undang manapun di seluruh dunia karena melanggar hak-hak dan dapat menimbulkan dampak buruk bagi perkembangan anak sehingga perlindungan anak harus diperhatikan (Soemitro, 1990). Child grooming merupakan proses mendekati anak dengan tujuan membujuk mereka agar bersedia melakukan aktivitas seksual. Pelaku menggunakan berbagai teknik untuk mengakses dan mengontrol korban. Proses ini membutuhkan akses, waktu, dan keterampilan interpersonal pelaku. Jika child grooming dilakukan dengan baik, korban secara tidak sadar akan mudah 'bekerjasama' dengan pelaku. Semakin mahir keterampilan pelaku dalam memilih dan merayu korban yang rentan, semakin sukses child grooming dilakukan. Keterampilan pelaku mencakup cara memilih korban, mengidentifikasi dan mengetahui kebutuhan korban, waktu yang dibutuhkan oleh pelaku untuk mendekati korban, merayu dan mengendalikan korban (Gill dan Harrison, 2015:34-49). 


\section{KERANGKA BERPIKIR}

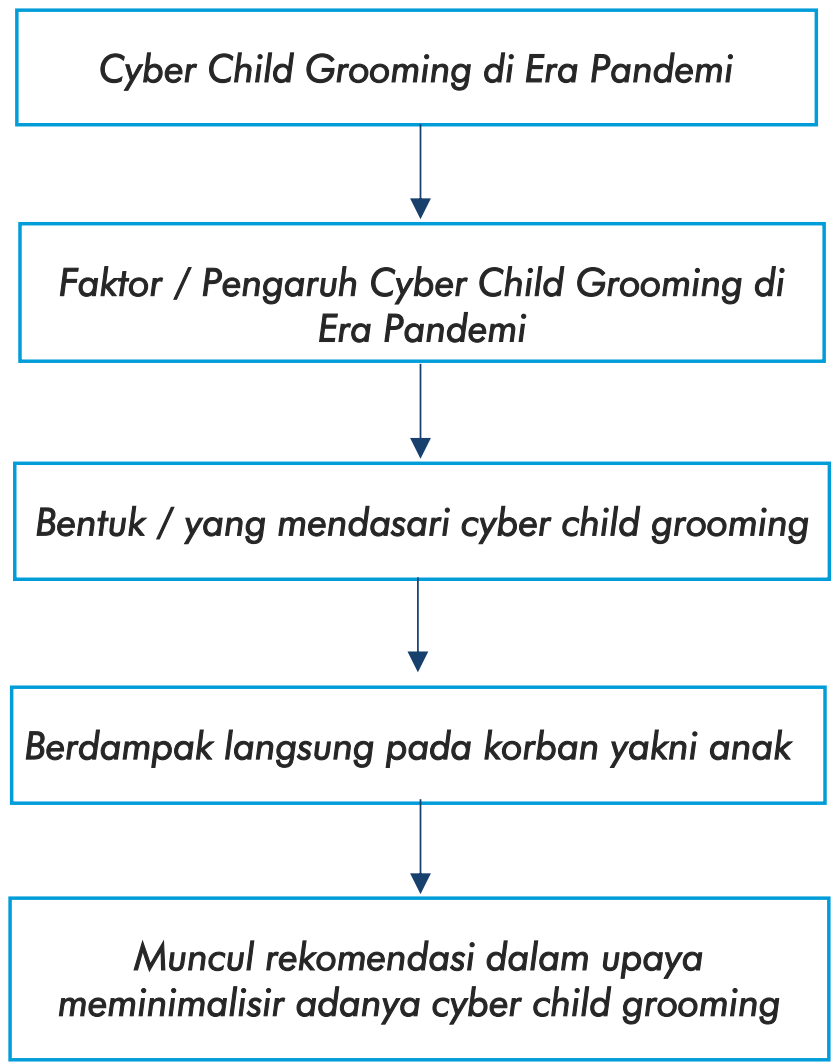

\section{METODOLOGI}

Penelitian ini akan menggunakan metode pendekatan penelitian kualitatif. Penelitian kualitatif yaitu, penelitian yang tidak menggunakan perhitungan, atau diistilahkan dengan penelitian ilmiah yang menekankan pada karakter alamiah sumber data. Sedangkan penelitian kualitatif menurut Sukmadinata yaitu suatu penelitian yang ditujukan untuk mendeskripsikan dan menganalisis fenomena, peristiwa, aktivitas sosial, sikap, kepercayaan, persepsi, pemikiran orang secara individu maupun kelompok (Moleong, 2002:2). Jenis penelitian menggunakan deskriptif analitis, dengan teknik pengumpulan data, yakni menggunakan studi literature mengenai bagaimana cyber child grooming di era pandemi, untuk dapat menghasilkan data penelitian yang diperlukan.

Data yang diperoleh adalah data sekunder seperti jurnal, artikel, skripsi atau disertasi, arsip dan buku yang sudah ada sebelumnya, yang berkaitan dengan topik penelitian ini. Artikel yang dipakai maksimal 10 tahun terakhir, dengan menggunakan kata kunci "Kekerasan anak, Kekerasan Berbasis Gender Online (KBGO), Child Grooming, Cyber Grooming, dll". Pengolahan data dilakukan setelah proses pengumpulan data selesai. Data yang diperoleh dari literatur-literatur dikumpulkan untuk selanjutnya diseleksi untuk kepentingan penulisan paper. 


\section{HASIL DAN PEMBAHASAN}

\section{Faktor penyebab Kekerasan pada Anak di masa pandemic Covid-19}

Merebaknya kasus Covid-19 membuat pemerintah mengeluarkan berbagai kebijakan, salah satunya adalah kebijakan Pembatasan Sosial Berskala Besar (PSBB) atau Social Ditancing sebagai tindakan pemerintah untuk mengurangi jumlah penularan Covid-19. Adanya kebijakan tersebut menimbulkan beberapa perubahan yang cukup besar di berbagai aspek kehidupan masyarakat, baik dalam aspek bidang ekonomi, politik, lingkungan, sosial maupun budaya, salah satu perubahan yang terjadi adalah adanya ketidaksiapan baik orangtua maupun anak. Disisi lain pandemi Covid-19 sangat berdampak dalam ekonomi masyarakat, khususnya ekonomi masyarakat menengah ke bawah. Perubahan kondisi ekonomi keluarga semakin memperburuk psikologis orang tua. Survei kesehatan jiwa yang dilakukan Perhimpunan Dokter Spesialis Kedokteran Jiwa Indonesia (PDSKJI) sejak bulan Maret 2010 di 31 provinsi dengan 5.661 peserta menunjukkan bahwa $68 \%$ peserta mengalami masalah psikologis (gatra.com, 14 Oktober 2020). Dalam kondisi ini anak berada pada posisi rawan akan kekerasan, kondisi anak tidak berdaya untuk melakukan perlawanan, sementara akses perlindungan baik informal (saudara, teman, tetangga atau guru) maupun formal (pelayanan perlindungan atau pelayanan sosial) terbatas selama PSBB.

Di dalam sistem pendidikan sendiri, pemerintah memberlakukan sistem pembelajaran daring atau disebut dengan Pembelajaran Jarak Jauh (PJJ). Dengan adanya PJJ tentunya membutuhkan fasilitas pendamping seperti gadget, penunjuang internet seperti, wifi, kuota internet dan sinyal, Salah satu faktor penyebab munculnya cyber child grooming adalah anak-anak juga akan menggunakan gadget dan media sosial lebih banyak disaat adanya sistem daring atau Pembelajaraan Jarak Jauh, anak-anak dituntut untuk bisa dan dapat menggunakan gadget guna memenuhi tugas ataupun pembelajaran di sekolah. Hal ini tentunya tidak hanya membawa dampak positif tetapi juga dapat berakibat negatif. Anak akan dengan mudah memperoleh informasi baik dalam bentuk foto, atau video yang tidak dapat dipertanggungjawabkan, salah satu contohnya adalah berita Hoax. Selain itu rendahnya pengetahuan orang tua turut menjadi faktor penyebab cyber child grooming di masa pandemi. Orang tua yang sering melupakan pengawasan, dan pola asuh terhadap anak, menjadikan kurang pentingnya keamanan dan lingkungan anak. Orang tua dalam mendidik atau mengasuh anak, menjadi faktor utama dan penting dalam pembentukan karakter anak. Selain itu dalam UU No. 23 Tahun 2002 tentang perlindungan anak bab IV kewajiban dan tanggung jawab orang tua yang terdapat dalam pasal 26 menegaskan "Bahwa pertanggung jawaban orang tua, keluarga masyarakat pemerintah dan negara merupakan rangkaian kegiatan yang dilandaskan secara terus menerus demi terlindungnya hak-hak anak." Pandemi menuntut orang tua untuk menggantikan peran guru selama berada di rumah. Diperlukan kesiapan orangtua dalam memberikan bimbingan dan pengarahan untuk anak serta mengawasi dalam menggunakan media sosial dan gadget

Faktor lain yang dapat menyebabkan munculnya cyber child grooming adalah faktor struktural yang telah mengakibatkan terjadinya hubungan yang dirasakan tidak seimbang bagi anak, baik pada lingkungan keluarga maupun di lingkungan masyarakat. Anak selalu berada pada posisi yang rawan mengalami tindak kekerasan karena kondisi fisik anak yang lebih lemah dibandingkan orang dewasa serta masih sangat tergantung kepada orang-orang di sekelilingnya. Bisa juga dari pengaruh lingkungan, seperti beredarnya video-video berbau porno, film porno, gambar-gambar porno dan lain sebagainya. Dengan adanya media tersebut menjadi pengaruh yang besar bagi yang melihatnya, akibatnya banyak terjadi penyimpangan seksual terutama oleh anak di bawah umur. 
Populernya penggunakan media sosial juga telah menghadirkan bentuk-bentuk baru kekerasan berbasis gender online (KBGO). Berdasarkan definisi Komisioner Tinggi Persatuan Bangsabangsa untuk Pengungsi (UNHCR), kekerasan bebasis gender diartikan sebagai kekerasan langsung pada seseorang yang didasarkan atas seks atau gender. Ini termasuk tindakan yang mengakibatkan bahaya atau penderitaan fisik, mental atau seksual, ancaman, paksaan, dan penghapusan kemerdekaan. Berdasarkan data pada catatan tahunan Komnas Perempuan 2019, sepanjang 2018 ada sebanyak 97 laporan kekerasan yang terjadi di dunia maya. Komnas Perempuan mengklasifikasikan laporan-laporan tersebut pada beberapa tipe KBGO, yakni revenge porn, malicious distribution, cyber harrasment, impersonation, cyber stalking, cyber recruitment, sexting, cyber hacking, and morphing. Dampak negatif dari pesatnya perkembangan Teknologi Informatika (IT) membuat munculnya berbagai jenis kejahatan khususnya bagi anak-anak. Nyatanya, anak-anak yang tidak dalam pengawasan orang tua dan menggunakan teknologi informatika sangat rentan untuk menjadi korban kejahatan child grooming. Perlindungan hukum oleh negara terhadap kasus ini sendiri masih kurang relevan digunakan sebagai dasar hukum yang tepat dibandingkan dengan akibat yang terjadi baik terhadap kerusakan mental dan psikis yang
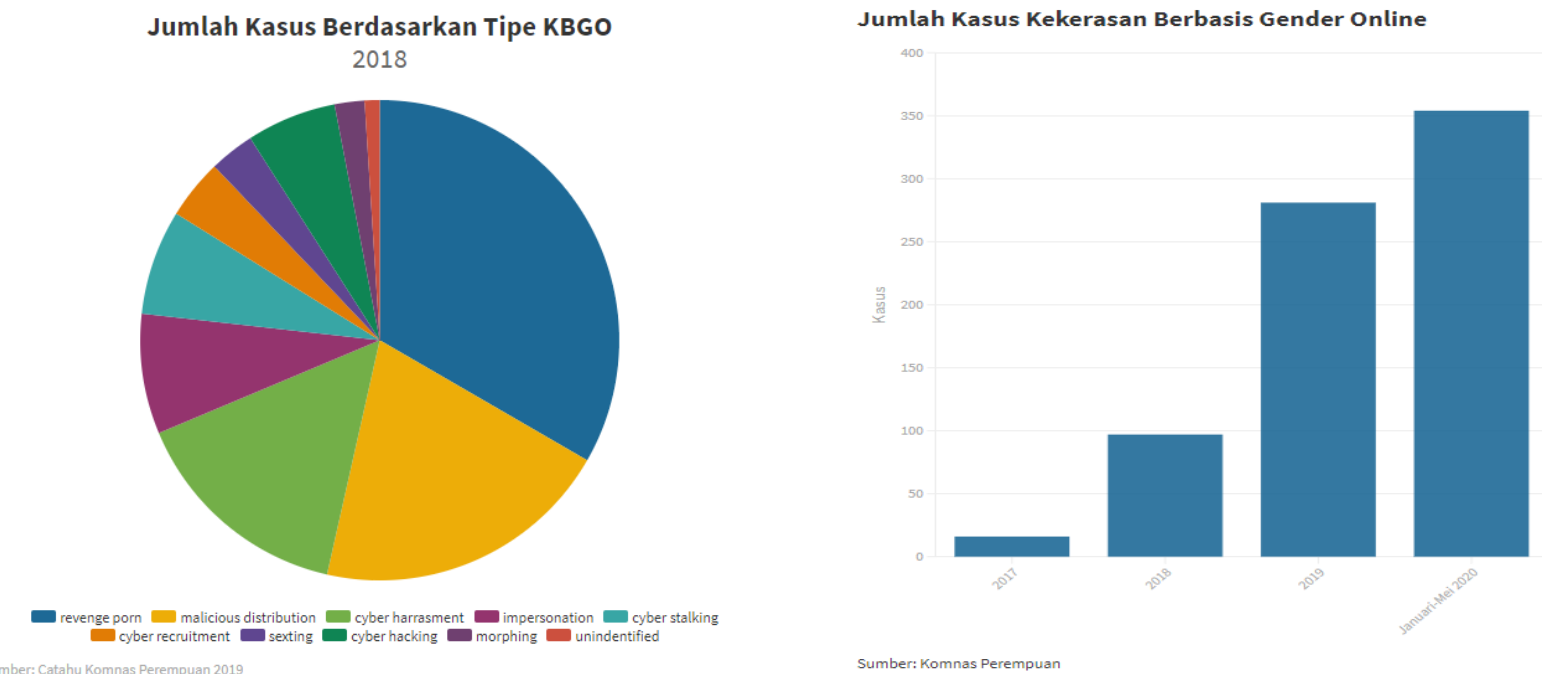

dialami korban dan keluarganya. Komnas Perempuan mencatat total kekerasan berbasis gender online (KBGO) sebanyak 354 kasus sepanjang Januari-Mei 2020 di semua ranah. Jumlah ini sudah lebih banyak dari total laporan pada 2019, 281 kasus. Sementara itu Dikutip dari berita kompas.com, direktur LBH Apik Jakarta Siti Mazumah mengatakan bahwa kasus KBGO juga turut menjadi sorotan karena anak-anak ikut menjadi korban. Bahkan, 16 dari 33 kasus cyber grooming menyasar korban anak. Kasus-kasus ini sangat sulit diproses karena sering kali anak enggan menginformasikan kepada orangtua terkait permasalahan yang dihadapi, biasanya disebabkan karena malu, atau takut apabila anak memberitahu kepada orangtuanya.

Bentuk Cyber Child Grooming sebagai bentuk Kekerasan Berbasis Gender Online di Masa Pandemi

Cyber child grooming dilakukan dengan berbagai tipe, durasi dan itensitas tergantung dari karakteristik dan perilaku masing-masing pelaku. Diantara berbagai cara dan variasi dalam melakukan online child grooming, terdapat enam hal umum yang mendasari cyber child grooming yaitu sebagai berikut (Sitompul, 2010:21): 


\section{Manipulation}

Cyber child grooming melibatkan beberapa bentuk manipulasi. Terdapat berbagai jenis manipulasi yang dapat dilakukan oleh pelaku terhadap korbannya. Berbagai teknik manipulasi digunakan untuk meningkatkan kekuatan dan kontrol pelaku terhadap korban serta meningkatkan ketergantungan korban pada pelaku seperti memberikan pujian untuk membuat korban merasa istimewa, sampai korban menjadi tertarik dan lengah. Cara manipulasi ini dilakukan agar korban merasa dicintai dan diperhatikan. Di sisi lain, pelaku dapat mengontrol korban dengan cara mengintimidasi sehingga korban merasa takut dengan pelaku dan tidak berani untuk melaporkan.

\section{Accessibility}

Kemudahan akses untuk berinteraksi dengan korban menjadi salah satu faktor terjadinya online child grooming. Pelaku dapat mengakses korban melalui internet tanpa harus bertatap muka secara langsung dan tanpa harus membuka identitas aslinya. Bahkan dapat mengambil data-data informasi sang anak, parahnya pelaku dapat mengendalikan korban hanya dengan melalui handphone atau gadget. Dalam dunia nyata, orang tua lebih berwaspada terhadap orang yang berinteraksi langsung dengan anak. Tetap, mereka malah tidak waspada dengan interaksi online dan kurang terlibat dalam kehidupan online anak mereka. Menurut penelitian, 20\% anak yang menggunakan jejaring sosial mengatakan pernah berbicara dengan orang asing di internet dan $20 \%$ diantara mereka berumur 9 hingga 12 tahun. Pelaku memanfaatkan teknologi internet untuk berinteraksi baik satu atau dua arah dengan korban melalui chat room, blog, media sosial, forum atau buletin.

\section{Rapport Building}

Sebagai bagian dari membangun hubungan, pelaku melakukan penyesuaian perilaku dan gaya berkomunikasi sehingga membuat korban nyaman berbicara dengan pelaku yang selanjutnya melakukan tindak kejahatan. Selain itu pelaku mencari tahu ketertarikan dan keadaan sekeliling korbannya, apa yang disukai atau yang membuat menarik korban dan bagaimana lingkungan sekeliling korban, sehingga saat korban lengah pelaku akan memulai tindakannya. Agar tindakan yang dilakukan oleh pelaku dengan korban tidak diketahui oleh orang lain, pelaku biasanya meminta korban merahasiakan hubungan mereka.

\section{Sexual Context}

Hubungan seksual merupakan tujuan online child grooming. Untuk kapan dan bagaimana hubungan seksualitas dimulai tergantung dari masing-masing pelaku. Pelaku akan memulai dengan cara yang bertahap, sehingga korban tidak akan curiga. Untuk memulai hubungan seksual dapat dilakukan dengan berbagai macam seperti berbicara jorok, merayu korban, mengirim gambar porno atau menghubungkan ke dalam hal-hal berbau pornografi.

\section{Risk Assessment}

Penilaian resiko terhadap korban dilakukan sebelum dan pada saat online child grooming. Penilaian resiko dilihat dari beberapa aspek yaitu individu korban, faktor yang berkaitan dengan internet dan lingkungan sekitarnya. Selain itu, pelaku melakukan manajemen resiko. Terdapat tiga cara yang dilakukan oleh pelaku dalam manajemen resiko, yaitu:

a. Berhubungan dengan teknologi yang digunakan dan logistik yang terkait dengan pelaku. Pelaku melakukan berbagai cara agar tidak mudah dilacak atau dikenali orang. Sebagai 
contoh menggunakan beberapa hardware, alamat IP yang berbeda, dan berbagai metode penyimpanan.

b. Pelaku menahan diri berkomunikasi dengan korban di ruang publik dan memilih penggunaan email pribadi atau ponsel.

c. Pelaku bertemu dengan korban dengan melakukan pertemuan yang jauh dari lingkungan korban. Namun, ada penelitian yang mengatakan bahwa managemen resiko tidak dimanfaatkan oleh semua pelaku, karena mereka mengganggap tidak melakukan sesuatu yang salah sehingga tidak ada yang perlu disembunyikan.

\section{Deception}

Dalam online child grooming, terkadang pelaku menyamar sebagai teman sebaya atau anak muda. Penelitian mencatat bahwa 5\% pelaku menyamar sebagai anak muda ketika berkomunikasi dengan korban. Sebagian besar pelaku memberitahu korban bahwa mereka adalah orang dewasa yang ingin membangun hubungan khusus dengan korban. Sebagian besar korban bertemu pelaku secara langsung dan melakukan hubungan seks. Sehingga dapat disimpulkan sebagian besar korban sadar mereka berkomunikasi dengan orang dewasa dan mengambil risiko untuk berinteraksi dengan pelaku.

\section{Dampak Cyber Child Grooming}

Semakin meningkatnya kasus kejahatan seksual salah satunya adalah Cyber Child Grooming mengakibatkan dampak negatif terhadap anak baik secara fisik maupun secara psikologis dan sosial. Mungkin kekerasan pada luka fisik dapat disembuhkan, namun apabila luka terhadap mental atau psikis anak belum tentu dapat disembuhkan bahkan dengan cepat, karena akan berdampak negatif pada masa depan anak tersebut. Beberapa dampak yang bisa diakibatkan oleh Cyber Child Grooming pada era pandemi sebagai berikut :

1. Kerugian Psikologis. Dapat menimbulkan kerugian psikologi, seperti depresi, tekanan, kecemasan, dan ketakutan. Bahkan pada titik tertentu para korban memiliki pikiran untuk menyakiti diri sendiri atau bahkan bisa sampai bunuh diri.

2. Keterasingan Sosial, korban cenderung akan menarik diri dari kehidupan sosial termasuk keluarga dan teman-teman. Hal tersebut berlaku untuk anak khususnya perempuan yang foto atau videonya disebar luaskan tanpa persetujuan dan membuat korban dipermalukan di tempat umum atau public (lebih menutup diri)

3. Mobilitas Terbatas, kehilangan kemampuan untuk bergerak bebas dan berpartisipasi dalam ruang baik online maupun offline.

4. Hilangnya kepercayaan diri dan sensor diri, hilangnya kepercayaan diri ini bisa terhadap orang-orang ataupun terhadap keamanan dalam menggunakan teknologi digital, putusnya komunikasi sosial, dll. 


\section{KESIMPULAN DAN REKOMENDASI KEBIJAKAN}

\section{Kesimpulan}

Populernya penggunaan media sosial juga telah menghadirkan bentuk-bentuk baru Kekerasan Berbasis Gender Online (KBGO), salah satunya adalah Cyber Child Grooming. Grooming merupakan upaya yang dilakukan seseorang untuk membangun hubungan, kepercayaan, dan hubungan emosional dengan seorang anak atau remaja sehingga mereka dapat memanipulasi, mengeksploitasi, dan melecehkan mereka. Faktor penyebabnya seperti kondisi anak tidak berdaya untuk melakukan perlawanan, dan kurangnya pengarahan dan bimbingan orangtua sebagai faktor penting dalam pembentukan karakter anak. Dengan meningkatnya Cyber Child Grooming, dapat mengakibatkan dampak negatif terhadap anak baik secara fisik maupun secara psikologis dan sosial. Sementara itu perlindungan hukum oleh negara terhadap kasus ini sendiri masih kurang relevan digunakan sebagai dasar hukum yang tepat dibandingkan dengan akibat yang terjadi baik terhadap kerusakan mental dan psikis yang dialami korban dan keluarganya.

\section{Rekomendasi Kebijakan}

Rekomendasi Kebijakan atau upaya yang dapat dilakukan untuk meminimalisir adanya cyber child grooming yakni: pertama, dimulai dari keluarga atau orangtua sebagai lingkungan terdekat anak. Diperlukan penguatan peran dan fungsi keluarga dalam pembentukan karakter anak. Orang tua diharapkan untuk tidak lalai dalam pengawasan saat anak bermain gadget atau media sosial. Orang tua dapat mengasuh dan membimbing anak dengan lebih perhatian dan menggunakan cara yang tepat, sehingga anak tumbuh dan berkembang dengan pribadi atau berkarakter baik. Kedua, masyarakat perlu meningkatkan kepedulian bagi perlindungan anak. Tidak hanya orang tua atau keluarga, partisipasi masyarakat juga turut andil dalam perlindungan anak. Ketiga, Media massa baik media elektronik maupun media cetak untuk meningkatkan edukasi berupa materi perlindungan anak terhadap masyarakat. Selain itu, diharapkan lebih banyak informasi-informasi, edukasi pengetahuan yang layak untuk ditonton, didengar ataupun dibaca oleh semua kalangan, khususnya anak-anak. Keempat, perlu adanya penegakan hukum yang lebih tegas dari aparat penegak hukum. UU tentang Perlindungan Anak sebenarnya sudah cukup berat memberikan aturan ketentuan sanksi pada pelaku kekerasan anak, namun kenyataan yang ditemui di lapangan seringkali tidak diterapkan dengan semestinya. Banyak aparat penegak hukum yang menjerat pelaku kekerasan pada anak hanya dengan pasal KUHP sehingga hukumannya menjadi ringan. Selain itu peraturan khusus mengenai child grooming di Indonesia tidak diatur secara spesifik. Untuk itu agar pelaku tetap mempertanggungjawabkan perbuatannya maka langkah yang diambil oleh penegak hukum adalah mengambil suatu kebijakan (yang merupakan diskresi aparat penegak hukum) dengan memfokuskan akibat eksploitasi seksual pada anak melalui internet tersebut dalam rangka upaya perlindungan hak-hak anak dengan melakukan pendekatan perundangan yaitu dapat dilakukan pendekatan perundangan pornografi.

\section{DAFTAR PUSTAKA}

\section{Buku}

Lexi J, Moleong. 2002. "Metodelogi Penelitian Kualitatif”. Bandung: PT. Remaja Rosda Karya.

Nana Syaodih Sukmadinata. 2007. "Metode Penelitian Pendidikan”. Bandung: PT. Remaja Rosdakarya. 
Romli Atmasasmita. 2013. "Teori Dan Kapita Selekta Kriminologi”. Revisi. Bandung: Refika Aditama.

Sitompul, A. 2010. "Hukum Internet”. Bandung: Citra Aditya Bakti.

Sofia Hardani and Wilaela. 2010. "Perempuan Dalam Lingkaran KDRT”. Riau: Pusat Studi Wanita, Universitas Islam Negeri Riau.

Jurnal

Anna Maria Salamor et al., 2020. "Child Grooming Sebagai Bentuk Pelecehan Seksual Anak Melalui Aplikasi Permainan Daring”. SASI 26, No. 4. Hal. 490-99.

De Vega, A., Hapidin, H., \& Karnadi, K. 2019. "Pengaruh Pola Asuh dan Kekerasan Verbal terhadap Kepercayaan Diri (Self-Confidence)". Jurnal Obsesi: Jurnal Pendidikan Anak Usia Dini, Vol. 3, No.2. Hal. 433-439.

Dik-dik, Manshur, M. A., 2015. Gultom, E. "Cyber Law: Aspek Hukum Teknologi Informasi”. Bandung: Refika Aditama,. Hal. 88

Gill, A. K., Harrison, K. 2015. "Child Grooming and Sexual Exploitation: Are South Asia Men the UK Media'S New Folk Devils”. International Journal for Crime, Justice and Social Democracy, No. 2. Hal. 34-49.

Kandedes, I. 2020 “Kekerasan Terhadap Anak Di Masa Pandemi Covid 19”. Jurnal Harkat: Media Komunikasi Gender, No. 1. Hal. 66-76.

Noviana, I. 2015. "Kekerasan seksual terhadap anak: dampak dan penanganannya". Sosio Informa, Vol. 1, No. 1.

Prameswari, J. R. C., Hehanussa, D. J. A., \& Salamor, Y. B., 2021. "Kekerasan Berbasis Gender Di Media Sosial,” PAMALI: Pattimura Magister Law Review, No. 1. Hal. 55-61.

Purwanti, A., Zalianti, Marzelina. 2018. "Strategi Penyelesaian Tindak Kekerasan Seksual Terhadap Perempuan dan Anak Melalui RUU Kekerasan Seksual”. Masalah-Masalah Hukum, No. 2. Hal. 138-148.

Salamor, A. M., Mahmud, A. N. F., Corputty, P., \& Salamor, Y. B., 2020. “Child Grooming Sebagai Bentuk Pelecehan Seksual Anak Melalui Aplikasi Permainan Daring”. SASI, No. 4. Hal. 490-499.

Suendra, D. L. O., \& Mulyawati, K. R. 2020. "Kebijakan Hukum Terhadap Tindak Pidana Child Grooming. Kertha Wicaksana". KERTHA WICAKSANA: Sarana Komunikasi Dosen dan Mahasiswa, No. 2. Hal. 118-123.

Artikel Online

Arum, N. 2019. "Mengenal Kekerasan Berbasis Gender Online (KBGO)." https://medium.com/@nendensan/mengenal-kekerasan-berbasis-gender-online-kbgoa4ec1bd95632. Diakses 28 Maret 2020.

Ridhoi, M. 2020. "Kekerasan terhadap Perempuan di Masa Covid-19". https://katadata.co.id/muhammadridhoi/analisisdata/5f69619121b54/kekerasan-terhadapperempuan-di-masa-covid-19. Diakses 2 April 2020. 
Sari, H. 2020. "LBH Apik: KDRT dan Kekerasan Berbasis Gender Online Meningkat sejak Pandemi,” https://nasional.kompas.com/read/2021/03/11/15344061/lbh-apik-kdrt-dankekerasan-berbasis-gender-online-meningkat-sejak-pandemi. Diakses 28 Maret 2020.

Wahyuni, Dinar. "Pencegahan Kekerasan Terhadap Anak Pada Masa Pandemi Covid-19", http://berkas.dpr.go.id/puslit/files/info_singkat/Info\%20Singkat-XII-22-II-P3DINovember-2020-218.pdf . Diakses 2 April 2020 